\title{
Effect of Chromium on Antioxidant Potential of Catharanthus roseus Varieties and Production of Their Anticancer Alkaloids: Vincristine and Vinblastine
}

\author{
Vartika Rai, ${ }^{1}$ Pramod Kumar Tandon, ${ }^{1}$ and Sayyada Khatoon ${ }^{2}$ \\ ${ }^{1}$ Department of Botany, University of Lucknow, Lucknow 226 007, India \\ ${ }^{2}$ Pharmacognosy \& Ethnopharmacology Division, CSIR-National Botanical Research Institute, Lucknow 226 001, India \\ Correspondence should be addressed to Vartika Rai; vartikarai@rediffmail.com and Sayyada Khatoon; sayyadak@yahoo.com
}

Received 25 April 2013; Revised 11 January 2014; Accepted 18 January 2014; Published 10 March 2014

Academic Editor: Sudhir Sopory

Copyright (C) 2014 Vartika Rai et al. This is an open access article distributed under the Creative Commons Attribution License, which permits unrestricted use, distribution, and reproduction in any medium, provided the original work is properly cited.

\begin{abstract}
Catharanthus roseus (L.) G. Don, a medicinal plant, has a very important place in the traditional as well as modern pharmaceutical industry. Two common varieties of this plant rosea and alba are named so because of pink and white coloured flowers, respectively. This plant comprises of about 130 terpenoid indole alkaloids and two of them, vincristine and vinblastine, are common anticancer drugs. The effect of chromium (Cr) on enzymatic and non-enzymatic antioxidant components and on secondary metabolites vincristine and vinblastine was studied under pot culture conditions of both varieties of C. roseus. Antioxidant responses of these varieties were analyzed under $0,10,50$, and $100 \mu \mathrm{M}$ chromium $(\mathrm{Cr})$ level in order to investigate the plant's protective mechanisms against $\mathrm{Cr}$ induced oxidative stress. The results indicated that $\mathrm{Cr}$ affects all the studied parameters and decreases growth performance. However, vincristine and vinblastine contents were increased under Cr stress. Results are quite encouraging, as this plant shows good antioxidant potential and increased the level of active constituents under Cr stress.
\end{abstract}

\section{Introduction}

The pollution is increasing in the environment by different kinds of human activities, which results in the accumulation of heavy metals in the soil and water and it causes different types of problems to the living beings [1]. Heavy metal contaminated lands are increasing in India day by day due to rapid industrialization, urbanization, and mining activities. One cannot use these lands for the agricultural purposes because, in that case, edible crops may accumulate high level of toxic metals which is detrimental for the health of people. In some previous experimental studies [2-5], it was observed that in higher concentration of heavy metals, the percentage yield of secondary metabolites, responsible for therapeutic activities, enhanced in medicinal plants. In this context, one can think on the line of increasing active constituents of some very important medicinal plants by growing them on otherwise wastelands contaminated with heavy metals. Plants, which are used in the modern drug industry and particularly have lower percentage of active constituents, may be selected for such type of study. In industrial crops, such as medicinal plants, the content of the economically important metabolite is more important than the yield of the plant part containing the metabolite, as it determines the cost of its extraction [6].

Catharanthus roseus (Linn.) G. Don is a renowned medicinal plant, belonging to the family Apocynaceae, and is a rich source of alkaloids, which are distributed in all parts of the plant. The plant contains about 130 alkaloids of the indole group out of which 25 are dimeric in nature [7]. Two of the dimeric alkaloids, vinblastine and vincristine mainly, present in the aerial parts, have found extensive application in the treatment of human neoplasma [8]. Vinblastine sulphate (sold as Velban) is used particularly to treat Hodgkin's disease besides lymphosarcoma, choriocarcinoma, neuroblastoma, carcinoma of breast and lungs, and other organs in acute and chronic leukemia. Vincristine sulphate (sold as Oncovin) arrests mitosis in metaphase and is very effective for treating acute leukaemia in children and lymphocytic leukemia. It is also used against Hodgkin's disease, Wilkins's tumor, 
neuroblastoma, and reticulum cell sarcoma [8]. High demand and low yield of these alkaloids in the plant have led to research for alternative means for their production.

Chromium (Cr) is selected as test metal because $\mathrm{Cr}$ compounds have various industrial uses and extensively employed in leather processing, production of refractory steel, and specialty chemicals. These anthropogenic activities have led to the widespread contamination of $\mathrm{Cr}$ and increased bioavailability and biomobility of Cr. The leather industry is the major cause for the high influx of $\mathrm{Cr}$ to the biosphere, accounting for $40 \%$ of the total industrial use [9]. In India, about 20000-32000 tons of elemental Cr annually escapes into the environment from tanning industries [10].

Cell and tissue culture and biotechnological aspects of C. roseus are being extensively investigated to increase the yield of these alkaloids $[11,12]$. Yet, comparatively very little work has been done on the effect of heavy metals on the antioxidant enzymes and alkaloids content of this economically important medicinal plant. Therefore, C. roseus has been selected for the present study to know the effect of chromium $(\mathrm{Cr})$ on its antioxidant potential and production of anticancer alkaloids vincristine and vinblastine. Two varieties of this plant, based on the flower colour, namely, pink flowered rosea and white flowered alba, were selected for the present study.

\section{Materials and Methods}

2.1. Sample Preparation. Seeds of the two varieties of Catharanthus roseus (L.) G. Don., that is, rosea and alba, were collected from the botanical garden of Lucknow. The experiments were conducted at the Department of Botany, Lucknow University. The seeds were surface sterilized in a $0.2 \% \mathrm{HgCl}_{2}$ solution for $5 \mathrm{~min}$ (with frequent shaking), and then thoroughly washed with tap water. The seeds were presoaked in $500 \mathrm{~mL}$ of water and were sown in specially prepared nursery in the field receiving normal daylight, temperature, and humidity. Plants having approximately the same height and weight were carefully uprooted after 45 days of sowing and transferred into the earthen pots $(300 \mathrm{~mm}$ diameter) filled with a garden soil $(5 \mathrm{Kg})$ mixed with potassium dichromate $\left(\mathrm{K}_{2} \mathrm{Cr}_{2} \mathrm{O}_{7}\right)$ in the concentration of 10,50 , and $100 \mu \mathrm{M}$. Three replicates for each concentration were made. The five seedlings approximately of $4 \mathrm{~cm}$ height and $1 \mathrm{~g}$ fresh weight (FW) were planted in each pot. The plants were watered daily and grown for 30 days and care was taken to avoid leaching of water from the pots. Plants in the soil without Cr treatment served as control. After harvesting, plants were washed under running tap water to remove the soil from root completely and again washed with glass distilled water. The roots and shoots were separated manually, just above the ground level.

2.2. Estimation of Chlorophyll. Chlorophyll was estimated by the method of Arnon [13] and absorbance was measured at 663, 645, 510, and $480 \mathrm{~nm}$ using Pharmacia Biotec, UV/Vis spectrophotometer.

2.3. Estimation of Protein. Protein was estimated by the methods of Lowry et al. [14]. $100 \mathrm{mg}$ plant material was homogenized with $3 \mathrm{~mL}$ of $10 \%$ trichloroacetic acid. The homogenate was centrifuged at 10,000 rpm and supernatant was discarded. The pellets obtained after centrifugation were treated with $3 \mathrm{~mL} 1 \mathrm{~N} \mathrm{NaOH}$, heated on water bath for 7 minutes and cooled down to room temperature. Again, the solution was centrifuged for five to ten minutes at $5000 \mathrm{rpm}$. Five $\mathrm{mL}$ reagent containing 100 parts of $2 \%$ solution of sodium carbonate and one part of $2 \%$ solution of sodium potassium tartrate was added to $0.5 \mathrm{~mL}$ of supernatant thus obtained after centrifugation and allowed it to stand for ten to fifteen minutes. Then $5 \mathrm{~mL}$ Folin and Ciocalteu's Phenol reagent (diluted with distilled water in ratio of $1: 1$ ) was added and allowed to stand for half an hour for development of colour, and then finally absorbance was measured at $700 \mathrm{~nm}$.

2.4. Estimation of Cysteine and Proline Contents. Known amount of plant material was extracted in $5 \%$ chilled $\mathrm{HClO}_{4}$ and centrifuged at $10000 \mathrm{rpm}$ for $20 \mathrm{~min}$ at room temperature. Cysteine content was measured in supernatant using acid ninhydrin reagent by reading absorbance at $560 \mathrm{~nm}$ [15]. Proline content was estimated by the method of Bates et al. [16]. The plant material was homogenized in $3 \%$ aqueous sulfosalicylic acid. The homogenate was centrifuged at $10000 \mathrm{rpm}$. Supernatant was used for the estimation of proline content. The reaction mixture consisted of $1.0 \mathrm{~mL}$ supernatant, $1.0 \mathrm{~mL}$ acid ninhydrin, and $1.0 \mathrm{~mL}$ glacial acetic acid, which was boiled at $100^{\circ} \mathrm{C}$ for $1 \mathrm{hr}$. After termination of reaction in ice bath, the reaction mixture was extracted with $4 \mathrm{~mL}$ of toluene and absorbance was read at $520 \mathrm{~nm}$.

2.5. Estimation of Nonprotein Thiol (NP-SH). For estimation of nonprotein thiol (NP-SH) content, plant tissue was extracted in $6.67 \% 5$-sulfosalicylic acid and centrifuged at $13,000 \mathrm{rpm}$ for $10 \mathrm{~min}$. Supernatant was reacted with Ellman's reagent. Absorbance was recorded at $412 \mathrm{~nm}$ [17].

2.6. Estimation of Lipid Peroxidation. The level of lipid peroxidation in fresh leaves was measured in terms of malondialdehyde (MDA) content by the thiobarbituric acid (TBA) reaction method [18]. $0.5 \mathrm{~g}$ fresh leaves was extracted with $5 \mathrm{~mL}$ of $1 \%$ TCA, and then centrifuged at $10000 \mathrm{rpm}$ for $5 \mathrm{~min}$. $0.5 \%$ TBA in $20 \%$ TCA was added in $1 \mathrm{~mL}$ of supernatant and heated at $95^{\circ} \mathrm{C}$ for $30 \mathrm{~min}$, quickly cooled on ice bath, and centrifuged at $10000 \mathrm{rpm}$ for $10 \mathrm{~min}$. Absorbance of the supernatant was taken at $532 \mathrm{~nm}$ and $600 \mathrm{~nm}$.

2.7. Assay of Antioxidant Enzymes. The samples were prepared as described by Mukherjee and Choudhuri [19]. Plant material was frozen in liquid nitrogen and finely ground by pestle in a chilled motor; the frozen powder was added to $10 \mathrm{~mL}$ of $100 \mathrm{mM}$ phosphate buffer $\left(\mathrm{KH}_{2} \mathrm{PO}_{4} / \mathrm{K}_{2} \mathrm{HPO}_{4}\right)$ pH 7.0, containing $0.1 \mathrm{mM} \mathrm{Na}{ }_{2}$ EDTA and $0.1 \mathrm{~g}$ of polyvinylpyrrolidone (PVP). The homogenate was filtered through four layers of cheese cloth and centrifuged at $15000 \mathrm{rpm}$ for $10 \mathrm{~min}$ at $4^{\circ} \mathrm{C}$. The supernatant obtained will be designated as crude enzyme extract and was used for various antioxidant enzyme assays. 
2.7.1. Ascorbate Peroxidase (APX; EC 1.11.1.11). Ascorbate peroxidase activity was measured in the leaves of the plant by the method of Nakano and Asada [20], estimating the ascorbate oxidation at $290 \mathrm{~nm}$. The activity was calculated using the extinction coefficient of $2.8 \mathrm{mM}^{-1} \mathrm{~cm}^{-1}$.

2.7.2. Guaiacol Peroxidase (GPX; EC 1.11.1.7). Guaiacol peroxidase was measured in plant, following the method of Hemeda and Klein [21]. Activity was calculated using the extinction coefficient of $26.6 \mathrm{mM}^{-1} \mathrm{~cm}^{-1}$ at $470 \mathrm{~nm}$ for oxidized tetraguaiacol polymer. One unit of peroxidase activity was defined as the calculated consumption of $1 \mu \mathrm{mol}$ of $\mathrm{H}_{2} \mathrm{O}_{2} \min ^{-1} \mathrm{~g}^{-1}$ fresh weight.

2.7.3. Catalase (CAT, EC 1.11.1.6). The activity of catalase (CAT) was measured monitoring $\mathrm{H}_{2} \mathrm{O}_{2}$ decomposition at $240 \mathrm{~nm}$ in $3 \mathrm{~mL}$ reaction mixture containing $50 \mathrm{mM}$ phosphate buffer ( $\mathrm{pH}$ 7.0), $15 \mathrm{mM} \mathrm{H}_{2} \mathrm{O}_{2}, 100 \mu \mathrm{L}$ homogenate, and $0.1 \%(\mathrm{v} / \mathrm{v})$ Triton $\mathrm{X}-100$ [22]. The activity was expressed in terms of $\mu \mathrm{mol}$ of $\mathrm{H}_{2} \mathrm{O}_{2}$ reduced $\mathrm{min}^{-1} \mathrm{~g}^{-1} \mathrm{FW}$ at $25 \pm 2^{\circ} \mathrm{C}$.

2.8. Estimation of Metal Concentration. $1 \mathrm{~g}$ dried powdered plant material of each treatment was taken and subjected to wet digestion in $3: 1, \mathrm{v} / \mathrm{v}, \mathrm{HNO}_{3}: \mathrm{HClO}_{4}$. Cr concentration was estimated in Atomic Absorption Spectrophotometer (Perkin-Elmer, A-Analyst 300) [23].

2.9. Estimation of Vincristine and Vinblastine through High Performance Thin Layer Chromatography. $1 \mathrm{~g}$ dried powdered plant material of each treatment was extracted with $20 \mathrm{~mL}$ methanol on water bath, consecutively three times. Methanol soluble extracts were filtered and concentrated at low temperature and reduced pressure. $10 \mathrm{mg} / \mathrm{mL}$ solution of each extract was prepared with methanol [24]. $1 \mathrm{mg}$ of standards-vinblastine and vincristine sulphate (Sigma) was dissolved in $1 \mathrm{~mL}$ of methanol. $20 \mu \mathrm{L}$ of plant extracts was applied on HPTLC precoated silica gel plates (E. merck $60 \mathrm{~F}_{254}$ ) with the help of CAMAG Linomat 5 applicator. The plates were eluted to the distance of $8.0 \mathrm{~cm}$ in the solvent system developed through trial and error basis in previously saturated twin trough chamber (CAMAG). The plates were scanned using CAMAG TLC Scanner 3 with software WinCats 3.2.1. Photographs of TLC plates were taken by the CAMAG video documentation unit Reprostar 3.

2.10. Statistical Analysis. All values reported in this work are means of three independent determinations. The mean values \pm SD are given in tables and graphs. All the data has been statistically analyzed by one-way analysis of variance (ANOVA) in randomized complete block design to check the variability of data and validity of results. Comparison between control and treatment was done by LSD test [25].

\section{Results}

When C. roseus plants were transplanted to soil containing variable concentrations of chromium, at the beginning they
TABLE 1: Chromium accumulation in C. roseus.

\begin{tabular}{lcccc}
\hline \multirow{4}{*}{ Cr. conc. } & \multicolumn{4}{c}{ Rosea accumulation (ppm) } \\
& Shoot & Root & Shoot & Root \\
\hline Control & n.d & n.d & n.d & n.d \\
$10 \mu \mathrm{M}$ & $2.79 \pm 0.12$ & $5.80 \pm 0.15$ & $2.78 \pm 0.13$ & $3.06 \pm 0.15$ \\
$50 \mu \mathrm{M}$ & $10.36 \pm 0.43$ & $15.67 \pm 0.56$ & $15.03 \pm 0.45$ & $31.4 \pm 0.98$ \\
$100 \mu \mathrm{M}$ & $25.96 \pm 0.85$ & $41.4 \pm 1.05$ & $25.28 \pm 0.64$ & $35.3 \pm 0.95$ \\
\hline
\end{tabular}

showed the symptoms of chlorosis and senescence. But after a period of one week of transfer, the plants gradually adapted and grew well. It seemed that after an initial shock plants grew well. Plants treated with $\mathrm{Cr}$ at 10 and $50 \mu \mathrm{M}$ levels grew normally as shown by leaf numbers, plant height, and biomass. Only at $100 \mu \mathrm{M}$ level there is some stunted growth (data not shown).

3.1. Chromium Accumulation and Its Effect on Chlorophyll and Carotenoids Content. C. roseus accumulated chromium in concentration dependent manner (Table 1). The amount of chromium accumulated by different plant tissues (roots $>$ leaves) varied significantly (ANOVA, $P<0.05$ ). Roots of rosea variety accumulated maximum amount (41.4 ppm DW) of chromium when exposed to $100 \mu \mathrm{M}$ chromium for 30 days. The maximum chromium (25.96 ppm DW) content in shoots was also recorded at the same concentration and in the same variety.

Chromium reduced the level of photosynthetic pigments (total chlorophyll, chlorophyll a, and chlorophyll b) in $C$. roseus (Figure 1(a)). The chromium toxicity to photosynthetic pigments was not very significant (ANOVA, $P>0.05$ ). It was observed that $100 \mu \mathrm{M}$ chromium treatment for 30 days reduced total chlorophyll, chlorophyll a, and chlorophyll b contents only by $8.52,5.39$, and $10.56 \%$ in rosea variety and $5.08,5.65$, and $4.72 \%$ in alba variety, respectively. Contrary to the results of chlorophyll, carotenoids content increases with the increasing concentration of $\mathrm{Cr}$ in the growth medium (Figure 1(b)). 54.5\% increase was observed in the carotenoids content of rosea variety at $100 \mu \mathrm{M}$ Cr level which is quite significant (ANOVA $P<0.05$ ), but in alba variety not much significant increase was noticed at any level of Cr treatment (Figure 1(b)).

3.2. Protein, Cysteine, Proline, and Nonprotein Thiol (NP$\mathrm{SH}$ ) Contents. The protein contents of the chromium treated plants were also found affected (ANOVA, $P<0.05$ ) by chromium level in the soil (Figure 1(c)). A maximum reduction of $24.43 \%$ in protein content was observed at $100 \mu \mathrm{M}$ concentration in alba variety of C. roseus, whereas in rosea variety $22.95 \%$ reduction was found in protein content at $100 \mu \mathrm{M}$ level.

Chromium significantly (ANOVA, $P<0.05$ ) increased the cysteine, proline, and nonprotein thiol (NP-SH) content in C. roseus leaves (Figures 1(d), 1(e) and 1(f)). The maximum increase in cysteine $(46.32 \%)$ was found at $100 \mu \mathrm{M}$ level in alba variety, whereas maximum increase in proline $(46.26 \%)$ and NP-SH (22.58\%) was recorded at $50 \mu \mathrm{M}$ level in alba 


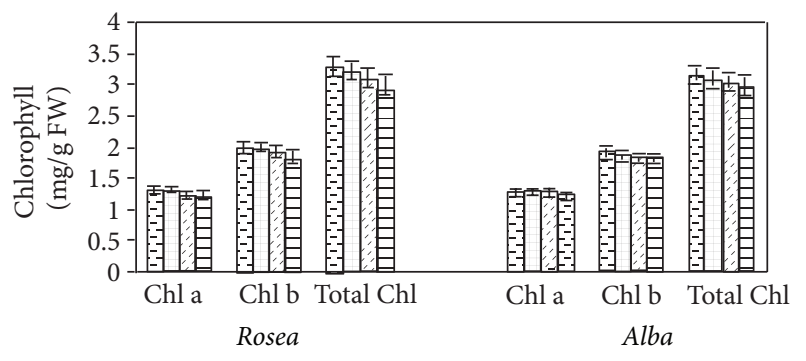

(a)

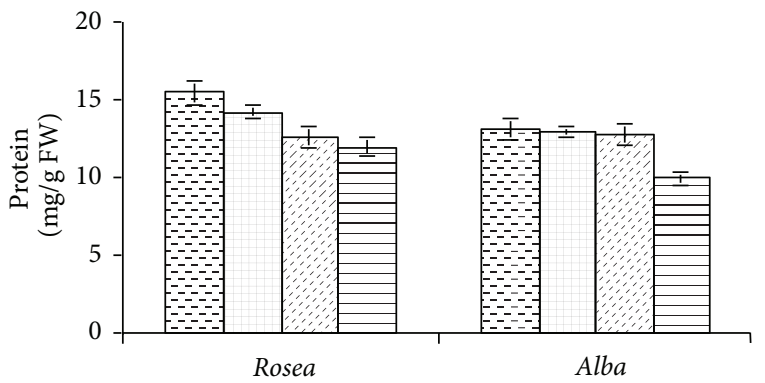

(c)

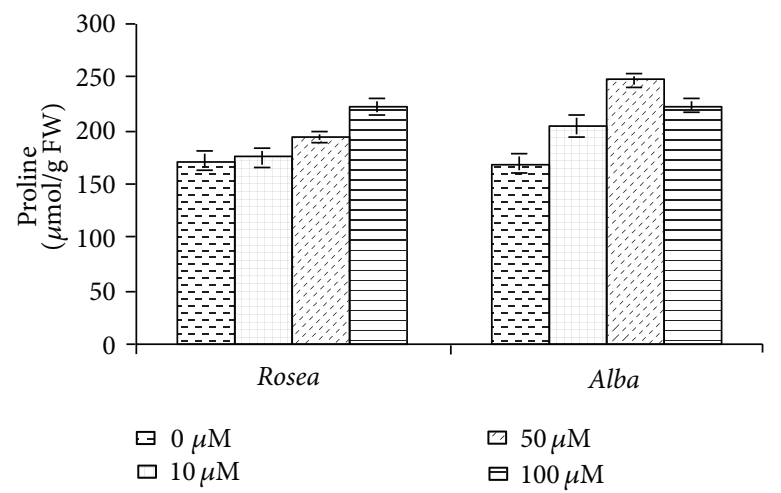

(e)

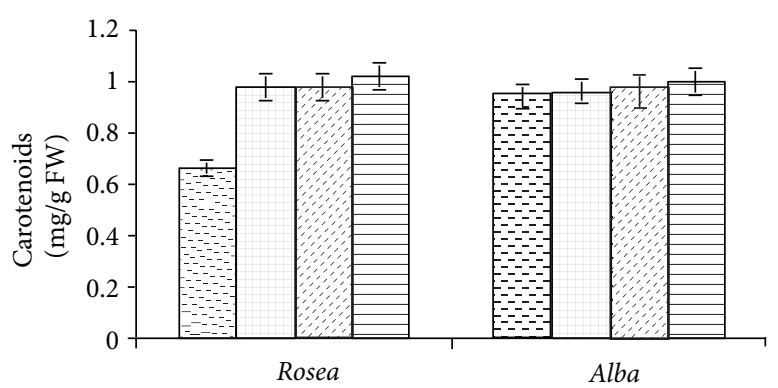

(b)

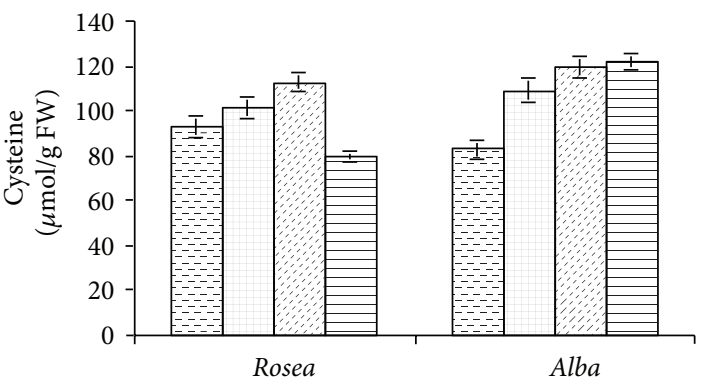

(d)

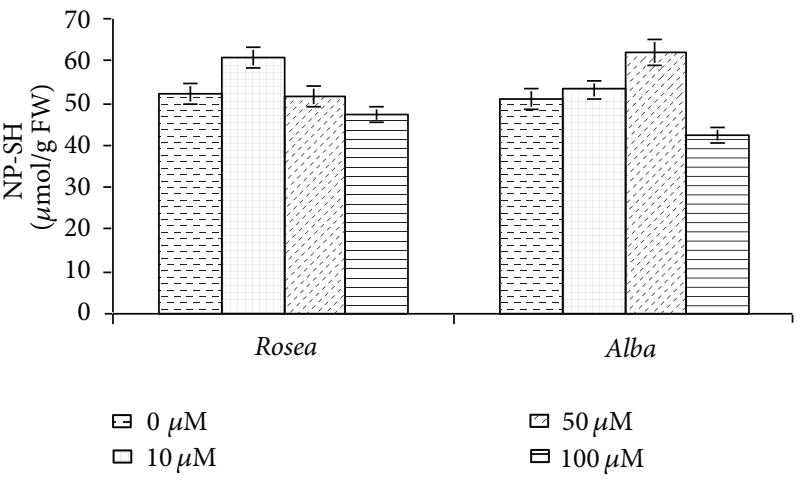

(f)

FIGURE 1: Effect of different chromium concentrations on (a) chlorophyll, (b) carotenoids, (c) protein, (d) cysteine, (e) Proline, and (f) NP-SH content of C. roseus after 30 days of Cr treatment. Mean \pm S.D. $(n=3)$. ANOVA, $P<0.05$.

variety. In the rosea variety cysteine increased up to $20.83 \%$ at $50 \mu \mathrm{M} \mathrm{Cr}$ level (Figure 1(d)), whereas proline and NP-SH increased up to $29.37 \%$ and $16.94 \%$ at 50 and $10 \mu \mathrm{M}$ level of $\mathrm{Cr}$, respectively (ANOVA, $P<0.05$ ) (Figures $1(\mathrm{e})$ and $1(\mathrm{f})$ ).

3.3. Lipid Peroxidation and Membrane Permeability. During present study, a significant (ANOVA, $P<0.05$ ) increase in malondialdehyde (MDA) content of $C$. roseus leaves was observed (Figure 2(a)) in the alba variety at $100 \mu \mathrm{M}$ chromium (after 30 days) in growth medium. It was noted that a maximum $19.53 \%$ increase of MDA content was found in the alba variety at $100 \mu \mathrm{M}$ level.

3.4. Antioxidant Enzymes. Heavy metal-induced reactive oxygen species in plants are quenched by a number of antioxidant enzymes. During the present study, it was observed that chromium toxicity resulted in a significant (ANOVA, $P<0.05$ ) hyperactivity of ascorbate peroxidase (APX), guaiacol peroxidase (GPX) and catalase (CAT) enzymes in C. roseus leaves (Figures 2(b), 2(c), and 2(d)). The maximum stimulation of APX activity (3.49-fold) was observed when rosea variety plants were exposed to $50 \mu \mathrm{M} \mathrm{Cr}$ and minimum at $100 \mu \mathrm{M}$ chromium exposure in alba variety (Figure 2(b)). However, peak stimulation of guaiacol peroxidase (GPX) (4.62 fold) was observed when plants were exposed to $100 \mu \mathrm{M}$ chromium in rosea variety for 30 days (ANOVA, $P<0.05)$ and minimum activity of GPX was found at $100 \mu \mathrm{M}$ chromium in alba variety (Figure 2(c)). Chromium significantly (ANOVA, $P<0.05$ ) increased the catalase activity at $50 \mu \mathrm{M} \mathrm{Cr}$ level in both varieties (Figure 2(d)). In the rosea variety 4.25 fold increase and in alba variety only 2.57 fold increases were found in catalase activity at $50 \mu \mathrm{M}$ Cr level. 


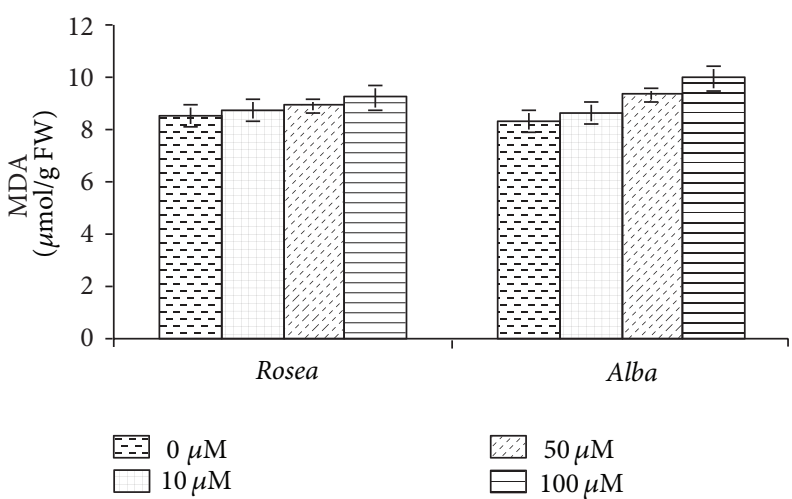

(a)

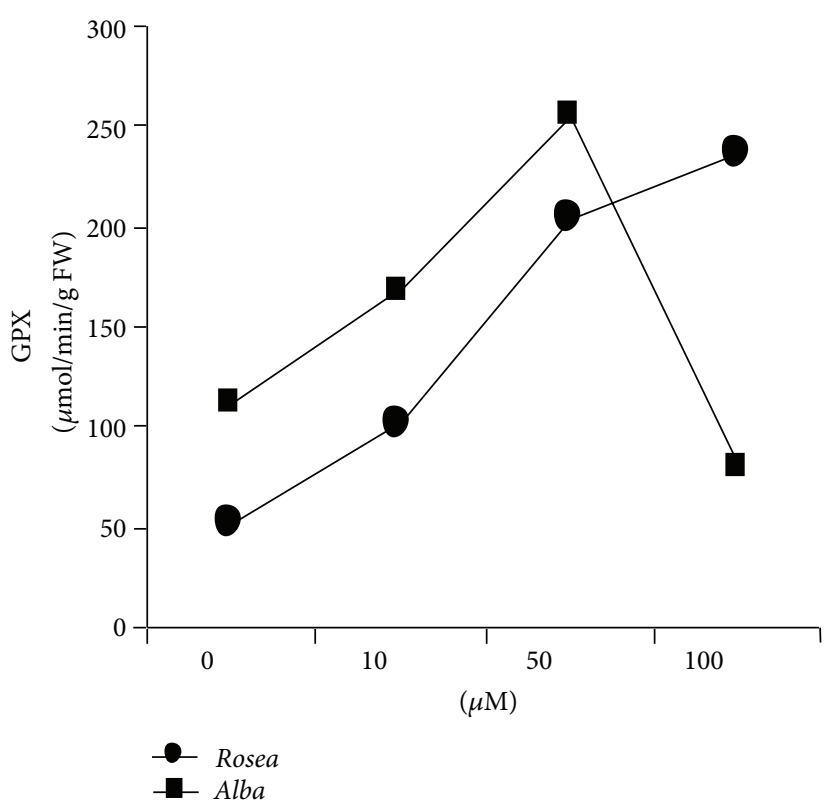

(c)

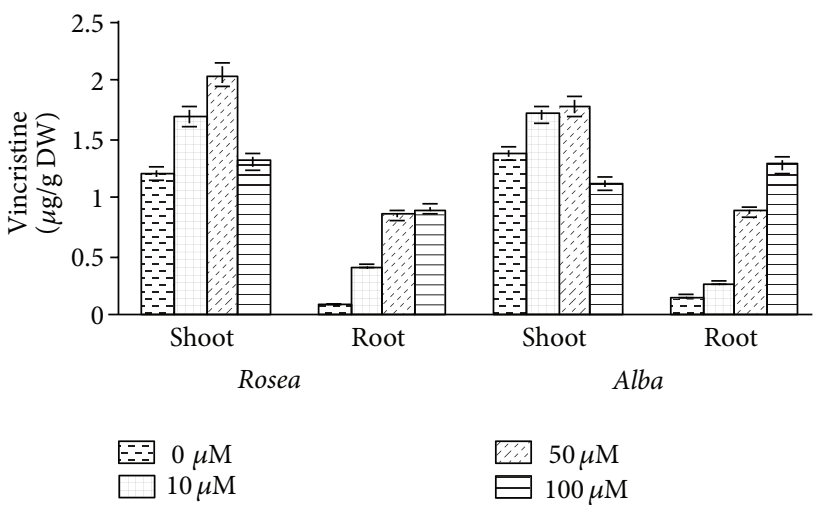

(e)
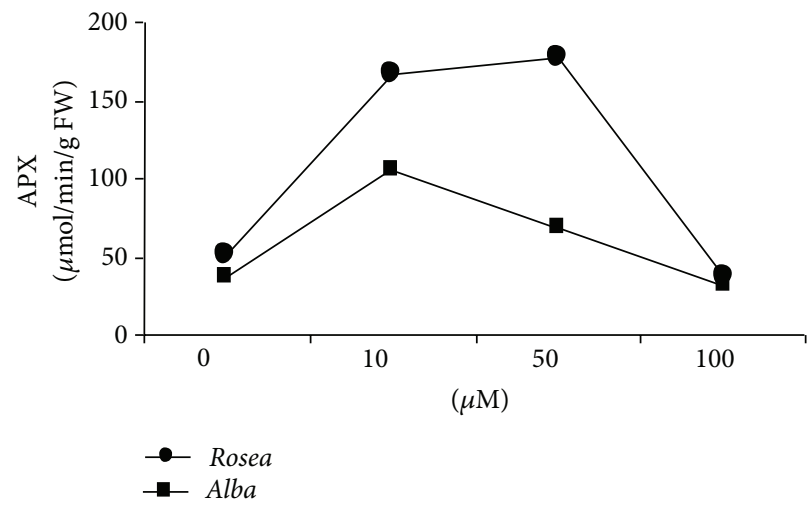

(b)

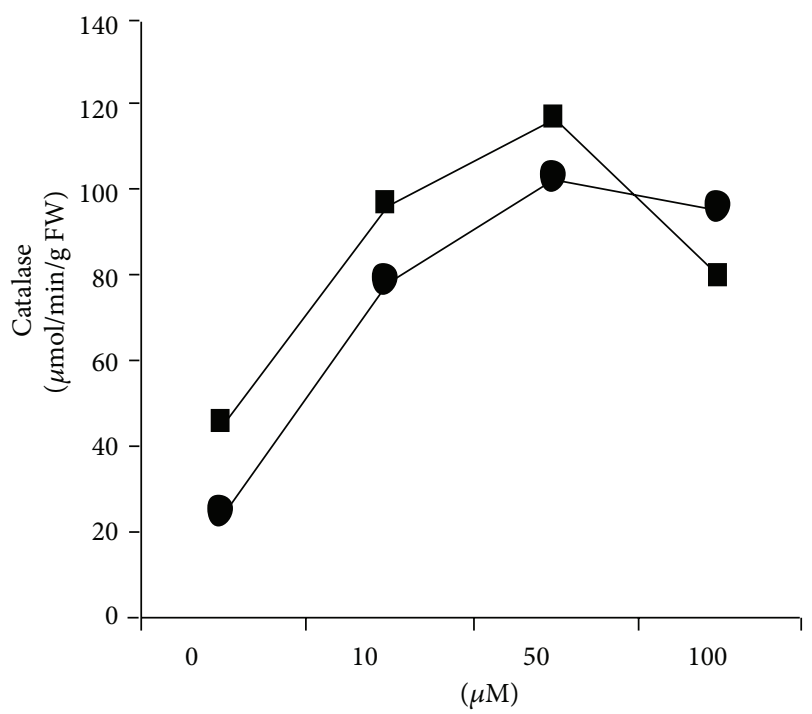

$\rightarrow$ Rosea

- - Alba

(d)

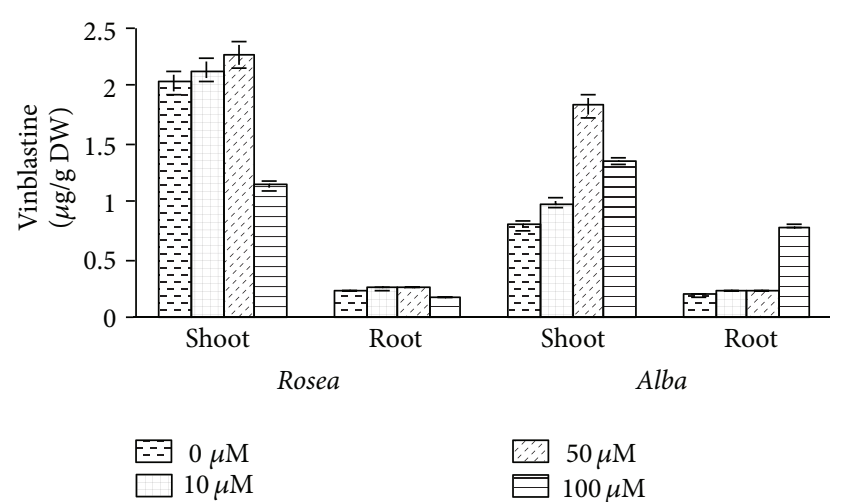

(f)

FigURE 2: Effect of different chromium concentration on (a) MDA, (b) APX, (c) GPX, (d) catalase, (e) vincristine, and (f) vinblastine content of $C$. roseus after 30 days of $C r$ treatment. Mean \pm SD $(n=3)$. ANOVA, $P<0.05$. 


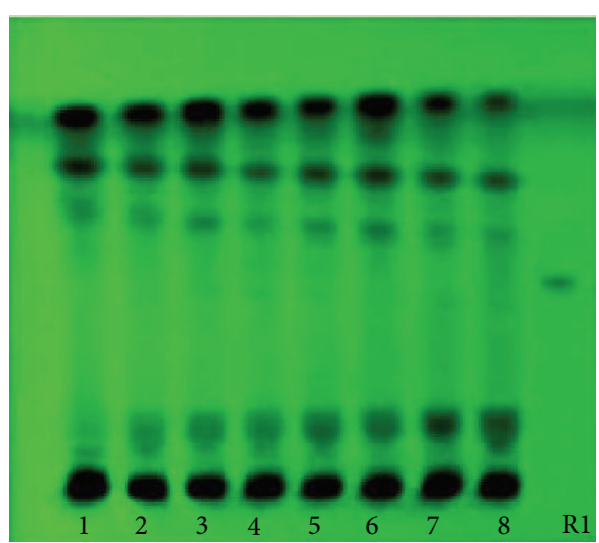

(a)

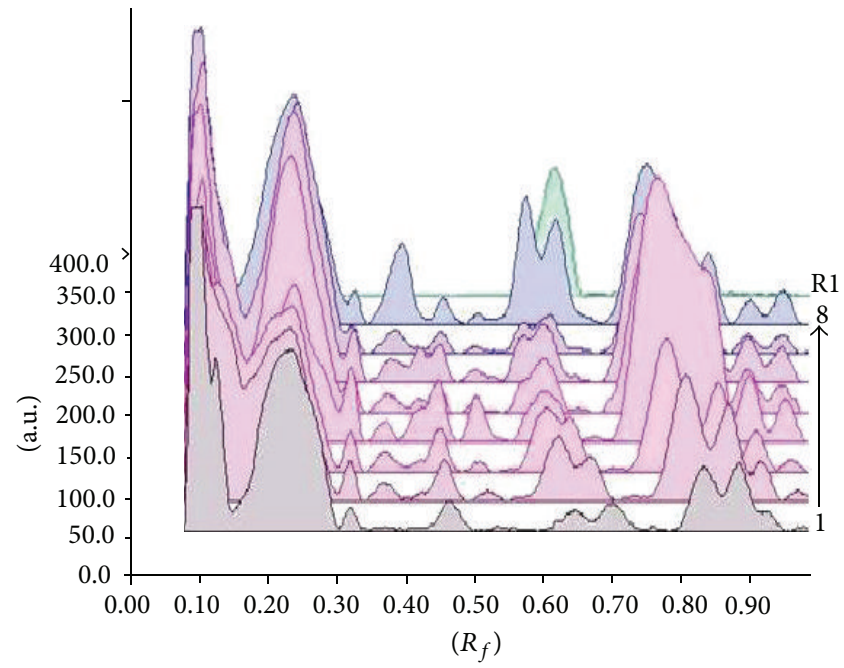

(c)

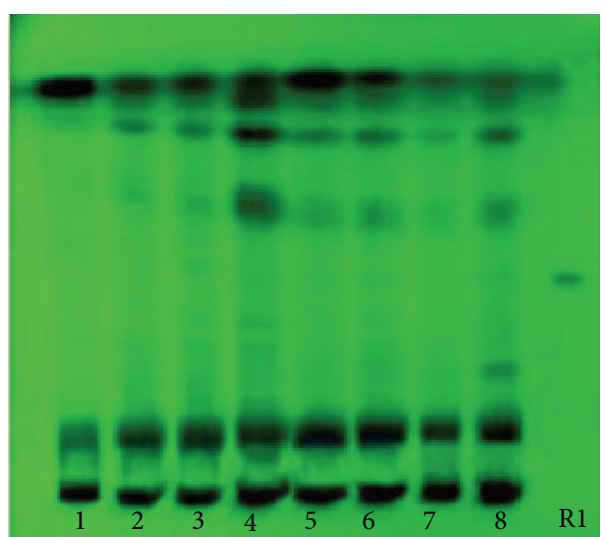

(b)

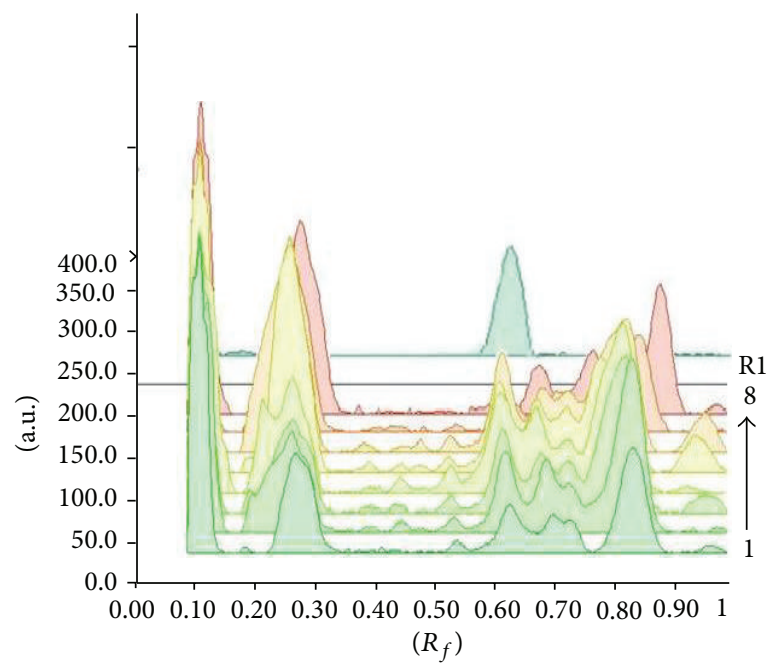

(d)

FIGURE 3: TLC fingerprint profile of methanolic extracts of control and treated plant along with marker compound of vincristine on HPTLC (E. Merck $60 \mathrm{~F}_{254}$ ) plate. 1-4: C. roseus variety rosea-control, 10, 50 and $100 \mu \mathrm{M}$; 5-8: C. roseus variety alba-control, 10, 50 and $100 \mu \mathrm{M}$; R1: vincristine marker. (a) Documentation of shoot samples under UV $254 \mathrm{~nm}$; (b) documentation of root samples under UV $254 \mathrm{~nm}$; (c) densitometric scan of shoot samples at $320 \mathrm{~nm}$; (d) densitometric scan of root samples at $320 \mathrm{~nm}$.

3.5. Vincristine and Vinblastine Content. Chromium treatment to $C$. roseus affected vincristine and vinblastine content-active constituents of the plant (Student's $t$-test, $P<0.05)$. The chromium concentrations in the growth medium enhanced the vincristine content significantly up to $100 \mu \mathrm{M} \mathrm{Cr}$ in the roots of both varieties, that is, rosea and alba (Figures 2(e) and 3), whereas in shoots it increases only up to $50 \mu \mathrm{M}$ Cr. $69.42 \%$ increase in vincristine content was observed in the shoots of rosea variety at $50 \mu \mathrm{M}$ chromium level (Figures 2(e) and 3). 2.29 fold increases in vinblastine content were found at the $50 \mu \mathrm{M}$ chromium level in the shoots of alba variety (Figures 2(f) and 4).

\section{Discussion}

C. roseus was able to tolerate $100 \mu \mathrm{M}$ chromium with some physiological and biochemical changes. This suggests this plant has a high adaptability to cope up with chromium stress.
The roots accumulated more chromium than the leaves in all treatments.

$\mathrm{Cr}$ is a toxic, nonessential element to plants; hence, they do not possess specific mechanisms for its uptake. Therefore, the uptake of this heavy metal is through carriers used for the uptake of essential metals for plant metabolism [26]. The reason of the high accumulation in roots of the plants could be because $\mathrm{Cr}$ is immobilized in the vacuoles of the root cells, thus rendering it less toxic, which may be a natural toxicity response of the plant [27].

Chromium reduced the foliar contents of total chlorophyll, chl a, and chl b contents in C. roseus. This might be attributed to the toxicity of chromium to chlorophyll biosynthesis of the test plant through direct inhibition of photosynthesis [28]. In agreement with our results, the degeneration of chlorophyll is the most common response observed in plants exposed to elevated concentrations of various heavy metals [4, 5, 29-31]. Carotenoid, a nonenzymatic antioxidant, plays an important role in protection of 


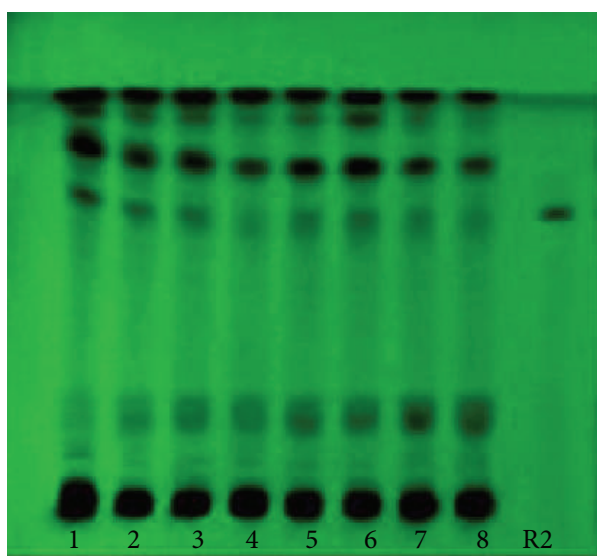

(a)

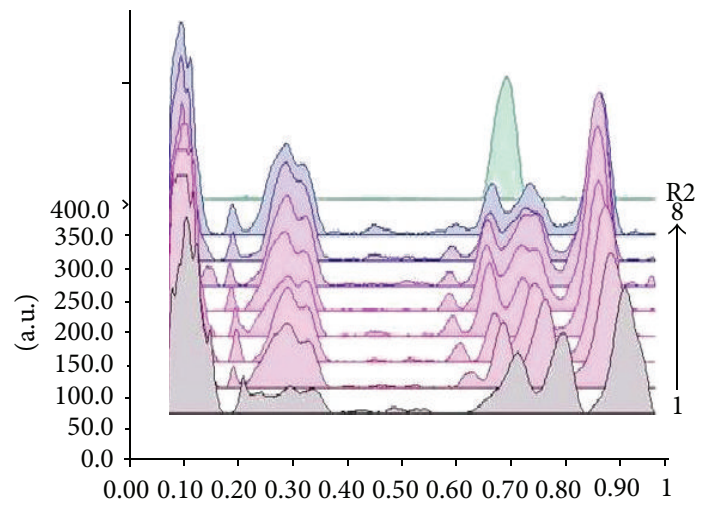

$\left(R_{f}\right)$

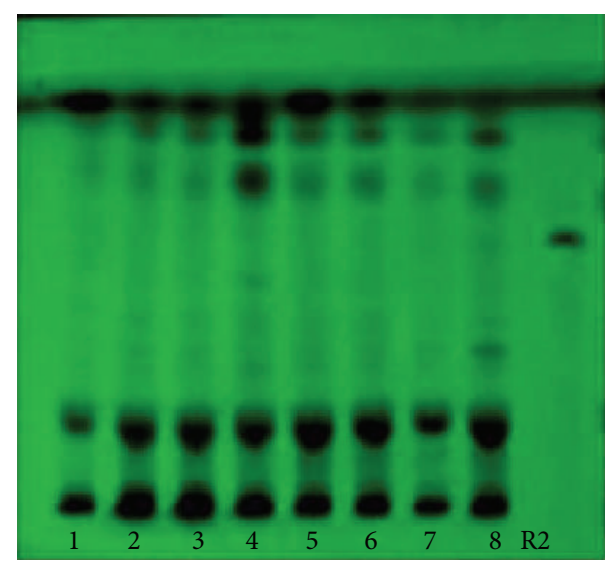

(b)

(c)

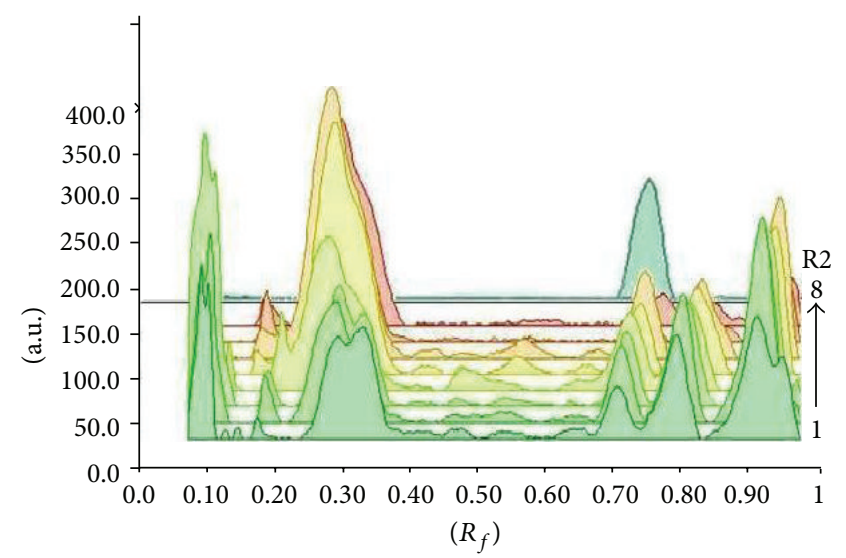

(d)

FIGURE 4: TLC fingerprint profile of methanolic extracts of control and treated plant along with marker compound of vinblastine on HPTLC (E. Merck $60 \mathrm{~F}_{254}$ ) plate. 1-4: C. roseus variety rosea-control, 10,50 and $100 \mu \mathrm{M} ; 5-8$ : C. roseus variety alba-control, 10,50 and $100 \mu \mathrm{M}$; R2: vinblastine marker. (a) Documentation of shoot samples under UV $254 \mathrm{~nm}$; (b) documentation of root samples under UV $254 \mathrm{~nm}$; (c) densitometric scan of shoot samples at $320 \mathrm{~nm}$; (d) densitometric scan of root samples at $320 \mathrm{~nm}$.

chlorophyll pigment under stress conditions by quenching the photodynamic reactions and replacing peroxidation [32]. In agreement with our results, increased carotenoid content was also observed in heavy metal rich industrial effluent exposed Capsicum annuum [33]. An increase in carotenoid contents is considered as defense strategy of the plants to combat metal stress as observed in the present study.

Chromium has been reported to reduce foliar protein content in plants $[31,34]$. In this case, also a small reduction in protein content was observed in chromium-treated C. roseus. As suggested by earlier workers [31,34], protein degradation might be the result of increased activity of the protease or other catabolic enzymes, which were activated under chromium stress. It is also likely that chromium induced lipid peroxidation in $C$. roseus and fragmentation of proteins due to toxic effects of reactive oxygen species which led to reduced protein content [35].

Some nonenzymatic antioxidants like cysteine, nonprotein thiol, proline, and carotenoids may play a role in inducing resistance to metals by protecting labile macromolecules against attack by free radicals which are formed during various metabolic reactions leading to oxidative stress [36, 37]. During the present study, induced levels of NP-SH, carotenoids, and cysteine were observed in Cr-treated plants. A high level of NP-SH content might enable metabolites to function in free radicals and ROS detoxification, which are reductively detoxified by concomitant oxidation of sulfhydryl moieties to disulfides [38]. In the present study, the level of nonenzymatic antioxidants like cysteine, proline, and nonprotein thiol exhibited varied response to $\mathrm{Cr}$ depending on the metal concentration. Many environmental stresses have been reported to increase the level of proline in plants, such as heavy metals, UV radiation, temperature, and drought [39, 40]. During the present study, higher accumulation of proline in chromium-treated plants of $C$. roseus has been observed which might be attributed to the strategies adapted by plants to cope up with chromium toxicity as proline has multiple functions, such as, scavenger of free radicals, protector role of cytoplasmic enzymes, source of nitrogen and carbon for post stress growth, stabilizer of membranes, machinery for protein synthesis, and a sink for energy to regulate redox potential [40]. 
The chromium accumulation in C. roseus leads to various physiological and biochemical changes. Chromium in $C$. roseus promoted MDA production (a cytotoxic product of lipid peroxidation) through excessive generation of free radicals. Chromium-induced loss of membrane permeability coupled with increased MDA production has also been observed in Vallisneria spiralis [34] and O. tenuiflorum [5]. Many other authors have also reported an increase in MDA content under metal stress [29, 41, 42].

Chromium induced reactive oxygen species in plants [34, $43,44]$. Further, to mitigate and repair the damage initiated by reactive oxygen species, plants have evolved a complex system involving antioxidant enzymes. Ascorbate peroxidase (APX) is the member of the ascorbic acid-glutathione cycle and plays a crucial role in eliminating poisonous $\mathrm{H}_{2} \mathrm{O}_{2}$ from plant cells. In this study, two chromium concentrations, that is, 10 and $50 \mu \mathrm{M}$ induced APX activity in C. roseus, only at $100 \mu \mathrm{M}$ Cr level APX activity inhibited. This is in agreement with the results earlier described in different plants growing under heavy metal stress $[45,46]$. Glutathione and free amino acids are known to induce heavy-metal tolerance by antioxidant action and metal chelating activity, respectively [47]. Recently, Zeng et al. reported that addition of glutathione (GSH) alleviated the reduction of plant growth and chlorophyll content but reduced malondialdehyde accumulation and increased the activities of the antioxidant enzymes in rice, suggesting that GSH may enhance antioxidant capacity in Cr-stressed plants [48]. Hence, it is possible that sulfate and iron supplementation can counter $\mathrm{Cr}$ toxicity in plants. It indicated that the activities of some antioxidant enzymes, including superoxide dismutase, catalase (CAT), and glutathione reductase, showed increase under Cr stress. Amongst various enzymes involved in quenching of reactive oxygen species, guaiacol peroxidase (GPX) and catalase have their importance in elimination of $\mathrm{H}_{2} \mathrm{O}_{2}$. The stimulated activities of these enzymes (GPX and catalase) found in this study led to the conclusion that elimination of $\mathrm{H}_{2} \mathrm{O}_{2}$ in $C$. roseus was achieved by APX, GPX, and catalase. Furthermore, GPX participates in the lignin biosynthesis and might build up a physical barrier against poisoning of the heavy metals. Therefore, hyperactivities of APX, GPX, and catalase in $C$. roseus might be attributed to the strategies adopted by the plant to overcome the toxicity of the chromium.

The secondary metabolites are formed under various stresses as a defense mechanism [2]. During the present investigation, chromium concentrations increased vincristine and vinblastine content in the treated plants. Vincristine and vinblastine are produced in vivo by the condensation of vindoline and catharanthine, both of which originate from the terpenoid indole alkaloid biosynthetic intermediate $(+)$-stemmadenine [49]. Vindoline, which is found only in the green parts of the plant, is biosynthesized from the branch-point intermediate tabersonine. This intermediate is formed from $(+)$-stemmadenine through the action of six enzymatic steps. These steps are sequentially catalysed by enzymes-T16H (tabersonine 16-hydroxylase), 16-hydroxytabersonine 16-O-methyltransferase (OMT), a hydroxylase (hydration), NMT (S-adenosyl-L-methionine:
16-methoxy-2,3-dihydro-3-hydroxy-tabersonine-N-methyltransferase), D4H (desacetoxyvindoline 4-hydroxylase), and acetyl-CoA: 4-O-deacetylvindoline 4-O-acetyl-transferase (DAT) [50]. Cacace et al. [51] identified Cr complex of flavonoid O-methyltransferase (OMT) and 16-hydroxytabersonine O-methyltransferase enzymes in cell cultures of $C$. roseus. It was noticed that flavonoid OMT does not synthesize flavonoids. Shukla et al. [49] reported 1-aminocyclopropane1-carboxylate oxidase, which catalyses the final step in the biosynthesis of ethylene that is formed in response to wounding and stress, as well as during senescence. In the present study $\mathrm{Cr}$ stress may produce ethylene which stimulates accumulation of vincristine and vinblastine in C. roseus. Recently, it has also been reported that there was an improvement of indole alkaloid production in cell cultures of $C$. roseus treated by various chemicals, elicitors, earth elements and bioregulators [52-57]. In cell suspension culture, if the glucose concentration is increased in the medium, the secologanin got increased simultaneously with increase in the terpenoid indole alkaloid production in Catharanthus plants [58].

\section{Conclusions}

It is concluded from the present study that waste lands with chromium contamination may be used for the cultivation of $C$. roseus. However, extensive trials are required to find out a proper level of $\mathrm{Cr}$ in each type of soil. At higher concentration, the plants may be used for the extraction of alkaloids, but the care should be taken to consume plant parts as such because, in that case, level of $\mathrm{Cr}$ may be higher than permissible limit.

\section{Conflict of Interests}

The authors declare no conflict of interests.

\section{Acknowledgments}

This research has been supported by Grant SR/FT/L-81/2006 from the SERC Division, Department of Science and Technology, New Delhi. The authors like to thank Mr. Prakash for assistance in collecting the seeds.

\section{References}

[1] D. C. Adriano, Trace Elements in the Terrestrial Environment, Springer, New York, NY, USA, 1986.

[2] G. E. Trease and G. E. Evans, Text Book of Pharmacognosy, Bailliera Tindall, London, UK, 2nd edition, 1989.

[3] A. Mithöfer, B. Schulze, and W. Boland, "Biotic and heavy metal stress response in plants: evidence for common signals," FEBS Letters, vol. 566, no. 1-3, pp. 1-5, 2004.

[4] V. Rai, S. Khatoon, S. S. Bisht, and S. Mehrotra, "Effect of cadmium on growth, ultramorphology of leaf and secondary metabolites of Phyllanthus amarus Schum. \& Thonn," Chemosphere, vol. 61, no. 11, pp. 1644-1650, 2005. 
[5] V. Rai, P. Vajpayee, S. N. Singh, and S. Mehrotra, "Effect of chromium accumulation on photosynthetic pigments, oxidative stress defense system, nitrate reduction, proline level and eugenol content of Ocimum tenuiflorum L.," Plant Science, vol. 167, no. 5, pp. 1159-1169, 2004.

[6] A. Levy, "Natural and induced genetic variation in the biosynthesis of alkaloids and other secondary metabolites," in Improvement of Oil Seed and Industrial Crops By Induced Mutations, pp. 213-222, IAEA, Vienna, Austria, 1982.

[7] R. van der Heijden, D. I. Jacobs, W. Snoeijer, D. Hallard, and R. Verpoorte, "The Catharanthus alkaloids: pharmacognosy and biotechnology," Current Medicinal Chemistry, vol. 11, no. 5, pp. 607-628, 2004.

[8] J. Aslam, S. H. Khan, Z. H. Siddiqui et al., "Catharanthus roseus (L.) G. Don. An important drug: it's applications and production," Pharmacie Globale (IJCP), vol. 4, no. 12, pp. 1-16, 2010, http://www.pharmacie-globale.info/.

[9] J. Barnhart, "Occurrences, uses, and properties of chromium," Regulatory Toxicology and Pharmacology, vol. 26, no. 1, part 2, pp. S3-S7, 1997.

[10] P. Chandra, S. Sinha, and U. N. Rai, "Bioremediation of Cr from water and soil by vascular aquatic plants," in Phytoremediation of Soil and Water Contaminants, E. L. Kruger, T. A. Anderson, and J. R. Coats, Eds., vol. 664 of ACS Symposium Series, pp. 2742782, American Chemical Society, Washington, DC, USA, 1997.

[11] P. R. H. Moreno, R. van der Heijden, and R. Verpoorte, "Cell and tissue cultures of Catharanthus roseus: a literature survey. II.Updating from 1988 to 1993," Plant Cell, Tissue and Organ Culture, vol. 42, no. 1, pp. 1-25, 1995.

[12] D. I. Jacobs, R. van der Heijden, and R. Verpoorte, "Proteomics in plant biotechnology and secondary metabolism reaserch," Phytochemical Analysis, vol. 11, no. 5, pp. 277-287, 2000.

[13] D. I. Arnon, "Copper enzyme in isolated chloroplast: polyphenol oxidase in Beta vulgaris," Plant Physiology, vol. 130, pp. 267272,1949 .

[14] O. H. Lowry, N. J. Rosebrough, A. L. Farr, and R. J. Randall, "Protein measurement with the Folin phenol reagent," The Journal of Biological Chemistry, vol. 193, no. 1, pp. 265-275, 1951.

[15] M. K. Gaitonde, "A spectrophotometric method for the direct determination of cysteine in the presence of other naturally occurring amino acids," Biochemical Journal, vol. 104, no. 2, pp. 627-633, 1967.

[16] L. S. Bates, R. P. Waldren, and I. D. Teare, "Rapid determination of free proline for water-stress studies," Plant and Soil, vol. 39, no. 1, pp. 205-207, 1973.

[17] G. L. Ellman, "Tissue sulfhydryl groups," Archives of Biochemistry and Biophysics, vol. 82, no. 1, pp. 70-77, 1959.

[18] R. L. Heath and L. Packer, "Photoperoxidation in isolated chloroplasts. I. Kinetics and stoichiometry of fatty acid peroxidation," Archives of Biochemistry and Biophysics, vol. 125, no. 1, pp. 189-198, 1968.

[19] S. P. Mukherjee and M. A. Choudhuri, "Implications of water stress induced changes in the levels of endogenous ascorbic acid and hydrogen peroxide in Vigna seedlings," Plant Physiology, vol. 58, pp. 166-170, 1983.

[20] Y. Nakano and K. Asada, "Hydrogen peroxide is scavenged by ascorbate-specific peroxidase in spinach chloroplasts," Plant and Cell Physiology, vol. 22, no. 5, pp. 867-880, 1981.

[21] H. M. Hemeda and B. P. Klein, "Effects of naturally occurring antioxidants on peroxidase activity of vegetable extracts," Journal of Food Science, vol. 55, pp. 184-185, 1990.
[22] H. Aebi, "Catalase in vitro," Methods in Enzymology, vol. 105, pp. 121-126, 1984.

[23] V. Rai, A. K. Agnihotri, S. Khatoon, A. K. S. Rawat, and S. Mehrotra, "Chromium in some herbal drugs," Bulletin of Environmental Contamination and Toxicology, vol. 74, no. 3, pp. 464-469, 2005.

[24] H. Wagner, S. Baldt, and E. M. Zgainski, Plant Drug AnalysisA Thin Layer Chromatographic Atlas, Springer, Berlin, Germany, 1984.

[25] K. A. Gomez and A. A. Gomez, Statistical Procedures for Agricultural Research, John Wiley \& Sons, New York, NY, USA, 1994.

[26] A. K. Shanker, C. Cervantes, H. Loza-Tavera, and S. Avudainayagam, "Chromium toxicity in plants," Environment International, vol. 31, no. 5, pp. 739-753, 2005.

[27] A. K. Shanker, M. Djanaguiraman, R. Sudhagar, C. N. Chandrashekar, and G. Pathmanabhan, "Differential antioxidative response of ascorbate glutathione pathway enzymes and metabolites to chromium speciation stress in green gram (Vigna radiata (L.) R.Wilczek. cv CO 4) roots," Plant Science, vol. 166, no. 4, pp. 1035-1043, 2004.

[28] F. van Assche and H. Clijsters, "Effect of metals on enzyme activities in plants," Plant, Cell and Environment, vol. 13, pp. 195206, 1990.

[29] S. M. Gallego, M. P. Benavídes, and M. L. Tomaro, "Effect of heavy metal ion excess on sunflower leaves: evidence for involvement of oxidative stress," Plant Science, vol. 121, no. 2, pp. 151-159, 1996.

[30] D. C. Sharma, C. P. Sharma, and R. D. Tripathi, "Phytotoxic lesions of chromium in maize," Chemosphere, vol. 51, no. 1, pp. 63-68, 2003.

[31] P. Vajpayee, R. D. Tripathi, U. N. Rai, M. B. Ali, and S. N. Singh, "Chromium (VI) accumulation reduces chlorophyll biosynthesis, nitrate reductase activity and protein content in Nymphaea alba L.", Chemosphere, vol. 41, no. 7, pp. 1075-1082, 2000.

[32] B. Halliwell, "Oxidative damage, lipid peroxidation and antioxidant protection in chloroplasts," Chemistry and Physics of Lipids, vol. 44, no. 2-4, pp. 327-340, 1987.

[33] R. K. Siddaramaiah, H. Ramakrishnaiah, S. Somashekar, and S. Subramanya, "Assessment of toxicity of heavy metal rich industrial effluents using germination and chlorophyll content tests," Journal of Industrial Pollution Control, vol. 14, no. 1, pp. 27-35, 1998.

[34] P. Vajpayee, U. N. Rai, M. B. Ali et al., "Chromium-induced physiologic changes in Vallisneria spiralis L. and its role in phytoremediation of tannery effluent," Bulletin of Environmental Contamination and Toxicology, vol. 67, no. 2, pp. 246-256, 2001.

[35] K. J. A. Davies, "Protein damage and degradation by oxygen radicals. I. General aspects," The Journal of Biological Chemistry, vol. 262, no. 20, pp. 9895-9901, 1987.

[36] R. A. Larson, "The antioxidants of higher plants," Phytochemistry, vol. 27, no. 4, pp. 969-978, 1988.

[37] U. Galli, H. Schüepp, and C. Brunold, "Thiols in cadmium- and copper-treated maize (Zea mays L.)," Planta, vol. 198, no. 1, pp. 139-143, 1996.

[38] S. Sinha and R. Saxena, "Effect of iron on lipid peroxidation, and enzymatic and non-enzymatic antioxidants and bacosidea content in medicinal plant Bacopa monnieri L.," Chemosphere, vol. 62, no. 8, pp. 1340-1350, 2006. 
[39] A. Saradhi and P. P. Saradhi, "Proline accumulation under heavy metal stress," Journal of Plant Physiology, vol. 138, pp. 554-558, 1991.

[40] N. P. Rout and B. P. Shaw, "Salinity tolerance in aquatic macrophytes: probable role of proline, the enzymes involved in its synthesis and C4 type of metabolism," Plant Science, vol. 136, no. 2, pp. 121-130, 1998.

[41] S. M. Gallego, M. P. Benavides, and M. L. Tomaro, "Oxidative damage caused by cadmium chloride in sunflower (Helianthus annuus L.) plants," Phyton, vol. 58, no. 1-2, pp. 41-52, 1996.

[42] S. Sinha, M. Gupta, and P. Chandra, "Oxidative stress induced by iron in Hydrilla verticillata (l.f.) Royle: response of antioxidants," Ecotoxicology and Environmental Safety, vol. 38, no. 3, pp. 286-291, 1997.

[43] V. Dixit, V. Pandey, and R. Shyam, "Chromium ions inactivate electron transport and enhance superoxide generation in vivo in pea (Pisum sativum L. cv. Azad) root mitochondria," Plant, Cell and Environment, vol. 25, no. 5, pp. 687-693, 2002.

[44] S. Samantary, "Biochemical responses of Cr-tolerant and Crsensitive mung bean cultivars grown on varying levels of chromium," Chemosphere, vol. 47, no. 10, pp. 1065-1072, 2002.

[45] A. Chaoui, S. Mazhoudi, M. H. Ghorbal, and E. El Ferjani, "Cadmium and zinc induction of lipid peroxidation and effects on antioxidant enzyme activities in bean (Phaseolus vulgaris L.)," Plant Science, vol. 127, no. 2, pp. 139-147, 1997.

[46] J. E. J. Weckx and H. M. M. Clijsters, "Oxidative damage and defense mechanisms in primary leaves of Phaseolus vulgaris as a result of root assimilation of toxic amounts of copper," Physiologia Plantarum, vol. 96, no. 3, pp. 506-512, 1996.

[47] W. E. Rauser, "Structure and function of metal chelators produced by plants: the case for organic acids, amino acids, phytin, and metallothioneins," Cell Biochemistry and Biophysics, vol. 31, no. 1, pp. 19-48, 1999.

[48] F. Zeng, B. Qiu, X. Wu, S. Niu, F. Wu, and G. Zhang, "Glutathione-mediated alleviation of chromium toxicity in rice plants," Biological Trace Element Research, vol. 148, no. 2, pp. 255-263, 2012.

[49] A. K. Shukla, A. K. Shasany, M. M. Gupta, and S. P. S. Khanuja, "Transcriptome analysis in Catharanthus roseus leaves and roots for comparative terpenoid indole alkaloid profiles," Journal of Experimental Botany, vol. 57, no. 14, pp. 3921-3932, 2006.

[50] V. de Luca, J. Balsevich, R. T. Tyler, U. Eilert, B. D. Panchuk, and W. G. W. Kurz, "Biosynthesis of indole alkaloids: developmental regulation of the biosynthetic pathway from tabersonine to vindoline in Catharanthus roseus," Journal of Plant Physiology, vol. 125, pp. 147-156, 1986.

[51] S. Cacace, G. Schröder, E. Wehinger, D. Strack, J. Schmidt, and J. Schröder, "A flavonol O-methyltransferase from Catharanthus roseus performing two sequential methylations," Phytochemistry, vol. 62, pp. 127-137, 2003.

[52] J. Zhao, W.-H. Zhu, Q. Hu, and Y.-Q. Guo, "Improvement of indole alkaloid production in Catharanthus roseus cell cultures by osmotic shock," Biotechnology Letters, vol. 22, no. 15, pp. 1227-1231, 2000.

[53] J. Zhao, W.-H. Zhu, Q. Hu, and X.-W. He, "Improved alkaloid production in Catharanthus roseus suspension cell cultures by various chemicals," Biotechnology Letters, vol. 22, no. 15, pp. 1221-1226, 2000.

[54] J. Zhao, W. H. Zhu, and Q. Hu, "Promotion of indole alkaloid production in Catharanthus roseus cell cultures by rare earth elements," Biotechnology Letters, vol. 22, no. 10, pp. 825-828, 2000 .
[55] J. Zhao, Q. Hu, Y.-Q. Guo, and W.-H. Zhu, "Elicitor-induced indole alkaloid biosynthesis in Catharanthus roseus cell cultures is related to $\mathrm{Ca}^{2+}$ influx and the oxidative burst," Plant Science, vol. 161, no. 3, pp. 423-431, 2001.

[56] J. Zhao, W. H. Zhu, and Q. Hu, "Enhanced catharanthine production in Catharanthus roseus cell cultures by combined elicitor treatment in shake flasks and bioreactors," Applied Microbiology and Biotechnology, vol. 55, pp. 693-698, 2001.

[57] J. Zhao, W.-H. Zhu, Q. Hu, and X.-W. He, "Enhanced indole alkaloid production in suspension compact callus clusters of Catharanthus roseus: impacts of plant growth regulators and sucrose," Plant Growth Regulation, vol. 33, no. 1, pp. 33-41, 2001.

[58] A. Contin, R. van der Heijden, A. W. M. Lefeber, and R. Verpoorte, "The iridoid glucoside secologanin is derived from the novel triose phosphate/pyruvate pathway in a Catharanthus roseus cell culture," FEBS Letters, vol. 434, no. 3, pp. 413-416, 1998. 

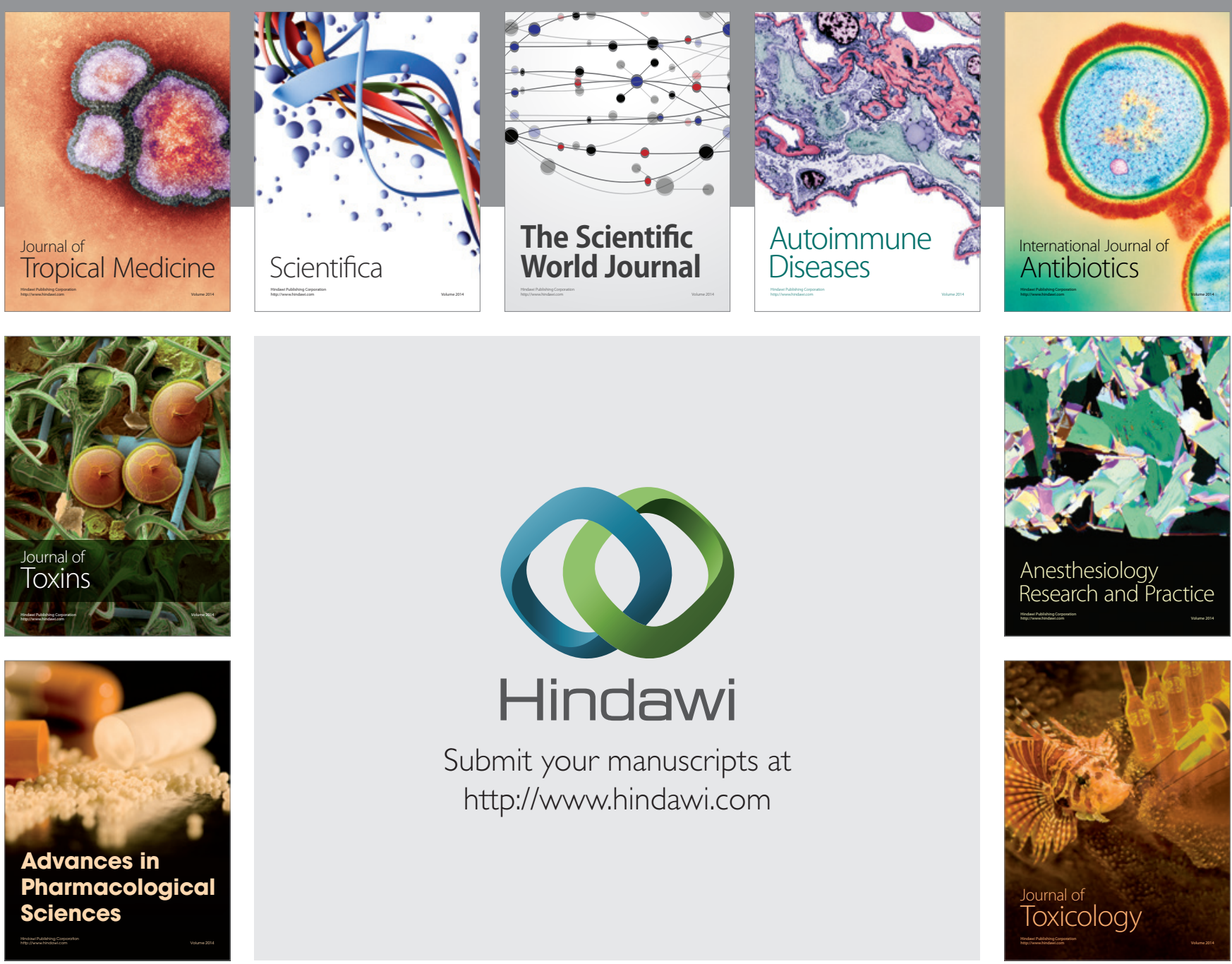

\section{Hindawi}

Submit your manuscripts at

http://www.hindawi.com
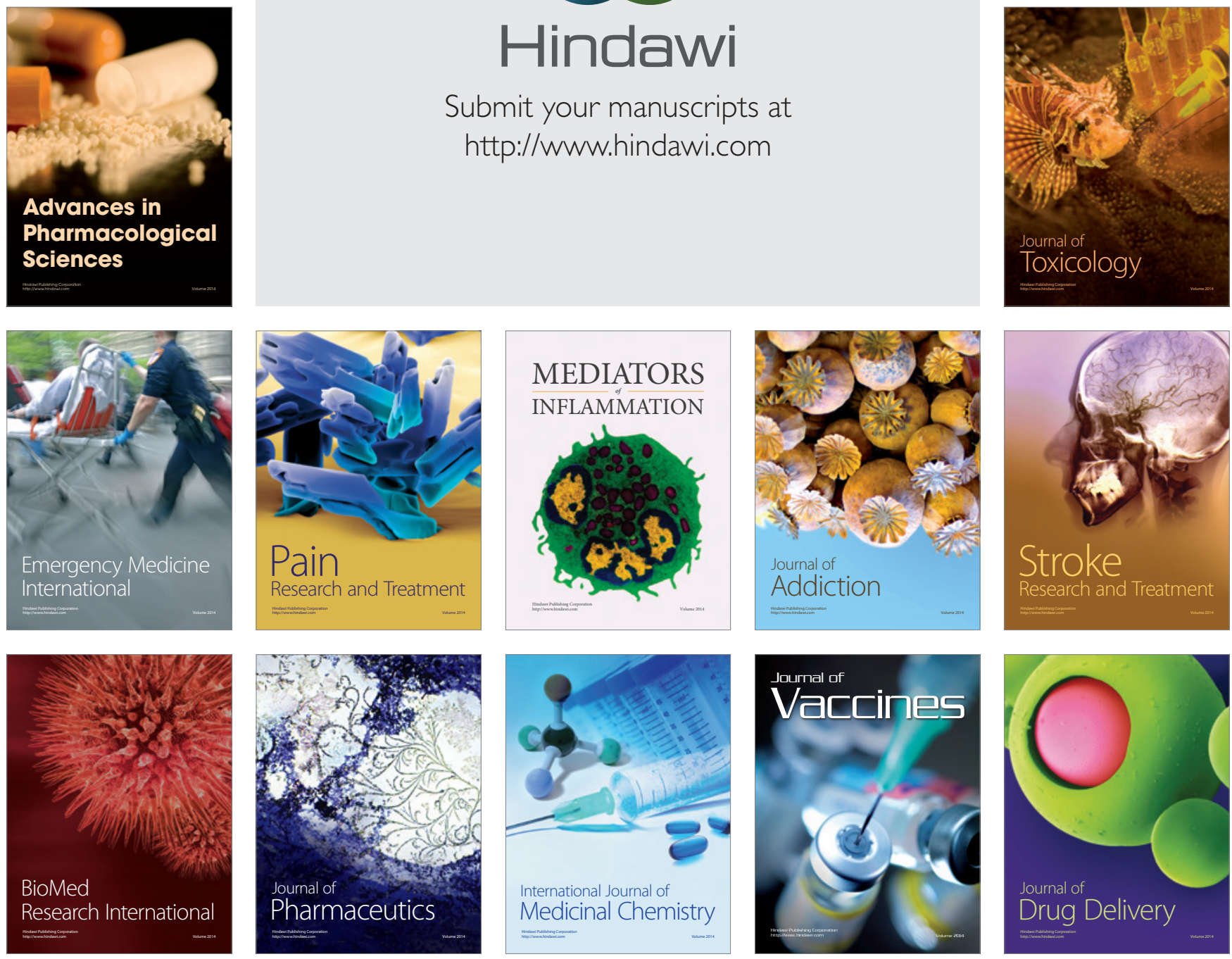